\title{
Investigations of the sediment thickness in Søndre Strømfjord, West Greenland
}

\author{
Birger Larsen
}

Søndre Strømfjord, approximately $170 \mathrm{~km}$ long, is a very clear example of a fjord formed by glacial processes. The bottom of the outer part of the fjord is U-shaped and situated only a few tens of metres below sea level. In the inner half of the fjord, north-east of Sarfartôq, the fjord is about $280 \mathrm{~m}$ deep and the sea bottom nearly horizontal for at least $40 \mathrm{~km}$. In the innermost part the bottom rises towards the large glacial river near the air base (data from Danish nautical charts nos. $1410,1411,1412$ ).

\section{Field work}

In 1974 a four-man team assisted by the crew of M/S Tycho Brahe completed a seismic section from off Angujârtorfik about $45 \mathrm{~km}$ from the air base to the mouth of the fjord (fig. 13). The equipment and interpretation techniques are as described by Denham (1974). Positions were determined by radar and sight to landmarks.

\section{Results}

The sedimentary cover on the Precambrian crystalline basement varies in thickness along the fjord. In the outer, shallow part of the fjord the cover is thin-mostly less than $20 \mathrm{~m}$ or in places absent. In the inner, deeper part of the fjord a $300-400 \mathrm{~m}$ thick sequence of sediments occurs (fig. 13).

The lowermost, uneven reflector is probably the surface of the basement. The rather thin, almost conformable cover on it is interpreted as moraine. This layer is unconformably covered by a thick sequence of horizontally stratified sediments, which form the recent sea bottom in the deepest parts of the fjord. This material is interpreted as muds deposited from the milky melt water which emerges into the fjord at several places (Frost, 1957). The velocity of sound in the sediments was not measured, but it is likely that the true thickness of the sediments is not more than indicated in fig. 13 and could be up to 25 per cent less.

The deep part of the fjord was deglaciated $8800-8000$ B.P. (Ten Brink \& Weidick, 1974). Assuming the above interpretation of the sequence is correct the $350 \pm 50 \mathrm{~m}$ thickness of sediments have been deposited in about 8400 years with an average rate of accumulation of $25 \mathrm{~mm} /$ year-approximately 25 per cent more if compaction of the mud is taken into account. This is in agreement with the high rate of silting observed in the dredged channel to Camp Lloyd, i.e. the port of Søndre Strømfjord airport (Frost, 1957).

According to Ten Brink \& Weidick (1974) the rate of retreat of the margin of the Inland Ice increased from an average of $2.5-3 \mathrm{~km} / 100$ years west of Sarfartôq (the shallow part of the fjord) to $5-10 \mathrm{~km} / 100$ years between Sarfartôq and Angujârtorfik (the deep part of the fjord). At the time of deglaciation the sea level was about $110 \mathrm{~m}$ above the present level. The sea in front of the ice was about $150 \mathrm{~m}$ deep in the shallow part of the fjord and some $700-800 \mathrm{~m}$ deep 


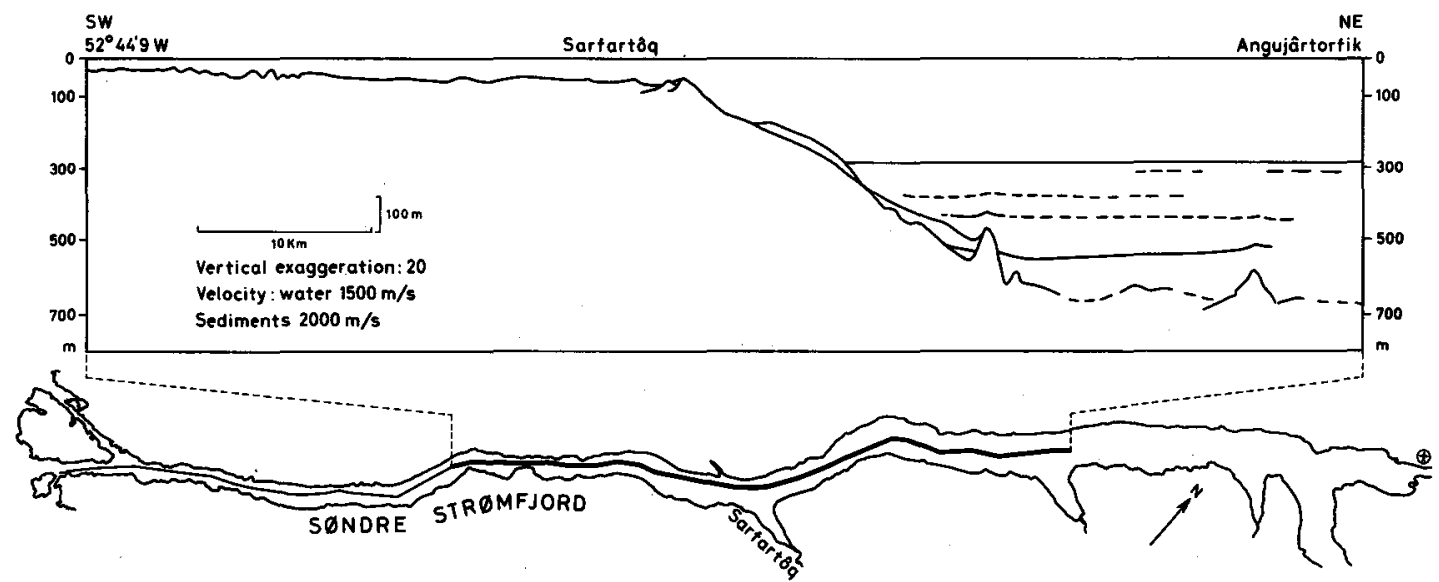

Fig. 13. Seismic section from the central part of Søndre Strømfjord, West Greenland.

in the deep part. It is likely that the deep water in front of the ice increased the rate of calving. This could possibly partly explain the observed high rate of glacial retreat in the deep part of the fjord.

\section{References}

Denham, L. R. 1974: Offshore geology of northern West Greenland $\left(69^{\circ}\right.$ to $\left.75^{\circ} \mathrm{N}\right)$. Rapp. Grønlands geol. Unders. 63, $24 \mathrm{pp}$.

Frost, R. E. 1957: A reconnaissance for a southern Greenland ice-cap access for military purposes. Tech. Rep. Snow Ice Permafrost Res. Establ. 46, 18 pp.

Ten Brink, N. W. \& Weidick, A. 1974: Greenland ice sheet history since the last glaciation. Quatern. Res. 4, 429-440.

Instituttet for Teknisk Geologi, Danmarks Tekniske Højskole, 2800 Lyngby, Denmark. 